\title{
Advances in the understanding of mitochondrial DNA as a pathogenic factor in inflammatory diseases [version 1; peer
}

\section{review: 3 approved]}

\author{
Ray K. Boyapati1,2, Arina Tamborska1, David A. Dorward1', Gwo-Tzer Ho (iD1 \\ ${ }^{1}$ MRC Centre for Inflammation Research Queens Medical Research Institute, University of Edinburgh, 47 Little France Crescent, \\ Edinburgh, EH16 4TJ, UK \\ ${ }^{2}$ Department of Gastroenterology, Monash Health, Clayton, VIC, Australia
}

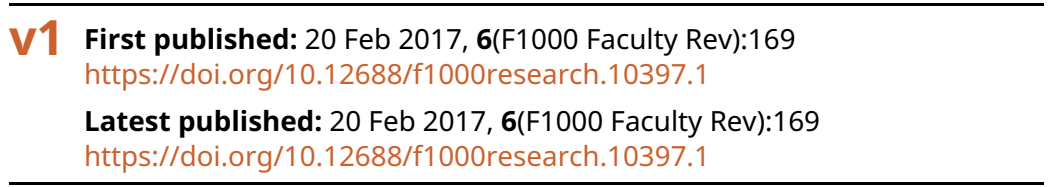

\section{Abstract}

Mitochondrial DNA (mtDNA) has many similarities with bacterial DNA because of their shared common ancestry. Increasing evidence demonstrates mtDNA to be a potent danger signal that is recognised by the innate immune system and can directly modulate the inflammatory response. In humans, elevated circulating mtDNA is found in conditions with significant tissue injury such as trauma and sepsis and increasingly in chronic organ-specific and systemic illnesses such as steatohepatitis and systemic lupus erythematosus. In this review, we examine our current understanding of mtDNAmediated inflammation and how the mechanisms regulating mitochondrial homeostasis and mtDNA release represent exciting and previously under-recognised important factors in many human inflammatory diseases, offering many new translational opportunities.

\section{Keywords}

mitochondrial DNA, mtDNA, mtDNA-mediated inflammation, inflammatory diseases

\section{Open Peer Review}

\section{Approval Status}

\section{1}

3

version 1

20 Feb 2017

Faculty Reviews are review articles written by the prestigious Members of Faculty Opinions. The articles are commissioned and peer reviewed before publication to ensure that the final, published version is comprehensive and accessible. The reviewers who approved the final version are listed with their names and affiliations.

1. Antonio Ferrante, University of Adelaide, Adelaide, Australia

2. Mitchell R. McGill, Washington University

School of Medicine, St Louis, USA

3. Augustine M.K. Choi, Weill Cornell Medicine, New York, USA

Kiichi Nakahira, Weill Cornell Medicine, New York, USA

Any comments on the article can be found at the end of the article. 
Corresponding author: Gwo-Tzer Ho (gho@staffmail.ed.ac.uk)

Competing interests: The authors declare that they have no competing interests.

Grant information: This work was supported by Medical Research Council grant G0701898, Crohn's and Colitis UK M16-1, ECCO IBD Investigator's Award 2010, Chief Scientist Office ETM/75 award (to G-TH); Edinburgh GI Trustees Grant (2014) (to RKB); Medical Research Society UK Vac-982-2016 (to AT); and Wellcome Trust grant WT096497 (to DAD).

The funders had no role in study design, data collection and analysis, decision to publish, or preparation of the manuscript.

Copyright: @ 2017 Boyapati RK et al. This is an open access article distributed under the terms of the Creative Commons Attribution License, which permits unrestricted use, distribution, and reproduction in any medium, provided the original work is properly cited.

How to cite this article: Boyapati RK, Tamborska A, Dorward DA and Ho GT. Advances in the understanding of mitochondrial DNA as a pathogenic factor in inflammatory diseases [version 1; peer review: 3 approved] F1000Research 2017, 6(F1000 Faculty Rev):169 https://doi.org/10.12688/f1000research.10397.1

First published: 20 Feb 2017, 6(F1000 Faculty Rev):169 https://doi.org/10.12688/f1000research.10397.1 


\section{Introduction}

Mitochondria are intracellular double-membrane-bound organelles ("cellular powerhouses") with many essential physiological roles in energy production, programmed cell death, calcium homeostasis, and the synthesis of lipids, amino acids, and haem. In addition, they are involved in antibacterial, antiviral, and stress responses to hypoxia and tissue injury ${ }^{1,2}$. Mitochondria are evolutionarily derived from energy-producing alpha-bacteria, engulfed by archezoan cells approximately 2 billion years ago leading to a symbiotic relationship that forms the basis of the eukaryotic cells $^{3}$. The mitochondria share several features with bacteria, including the double-membrane structure, a circular genome that replicates independently of nuclear DNA, and the synthesis of $\mathrm{N}$-formylated proteins ${ }^{4}$. As the innate immune system recognises conserved bacterial molecules, mitochondrial constituents are similarly immunogenic, acting as damage-associated molecular patterns (DAMPs) when released into the cytosol and extracellular environment, triggering innate immune responses, and promoting inflammation ${ }^{5}$. In this review, we focus particularly on the role of mitochondrial DNA (mtDNA) as a specific inflammatory factor, the mechanisms behind its abnormal release, and its effects on downstream inflammatory pathways in human inflammatory diseases.

\section{Elevated circulating mtDNA in human diseases}

Freely circulating mtDNA can be detected, and over 60 studies have quantified mtDNA by quantitative polymerase chain reaction (PCR) in plasma and serum in human diseases (Table 1). In general, they are increased in conditions with acute tissue injury such as trauma, acute myocardial infarction, and sepsis, implicating major cellular stress and uncontrolled cell death as key factors in the release of mtDNA (Figure 1). In cancer, where its role as "liquid biopsies" is a topic of considerable interest, the pattern is less clear, and relatively lower circulating levels are found in some cancers ${ }^{6}$.

\section{Systemic inflammatory response syndrome}

Systemic inflammatory response syndrome (SIRS) is a serious condition associated with high mortality, and affected individuals display progressive signs or symptoms of systemic upset reflecting widespread inflammation, often involving multiple organ dysfunction and failure (for example, lungs, kidneys, and brain). SIRS is often a result of major sepsis but also commonly occurs in the context of injury such as trauma. An early study by Lam et al. found that individuals admitted for blunt traumatic injury had increased plasma nuclear DNA and mtDNA levels ${ }^{7}$. Subsequently, Hauser et al. made the seminal observation that it is the freely circulating mtDNA following traumatic injury which possesses the distinct ability to trigger and drive the clinical manifestation of SIRS ${ }^{8}$. Several studies have confirmed the observation of elevated plasma mtDNA in trauma and SIRS ${ }^{9-15}$. A number of studies have found correlations with injury severity in trauma ${ }^{7,11}$ and higher mtDNA in non-survivors compared with survivors ${ }^{11,15}$. Furthermore, $\mathrm{Gu}$ et al. found that elevated plasma mtDNA was an independent predictor of SIRS in trauma patients ${ }^{12}$. In sepsis, elevated levels of circulating mtDNA have also been found in multiple studies ${ }^{11,16-21}$. De Caro et al. found higher mtDNA in the plasma of critically ill paediatric patients who were septic compared with similarly unwell but non-septic patients ${ }^{21}$. The one negative study in sepsis may be explained by numerous factors, including a relatively well patient cohort, only one "spot" measurement being taken at presentation, and the potentially confounding factor of cellular content/debris ${ }^{22}$. Studies of patients in the intensive care setting have found that higher mtDNA levels are associated with poorer outcomes ${ }^{23,24}$.

\section{Acute single-organ injury: liver, heart, and brain}

High levels of mtDNA are present in the serum and plasma of patients with acute injury to a variety of single organs. Acetaminophen overdose induces massive hepatocyte necrosis and in severe cases can lead to multi-organ failure and remains one of the commonest indications for liver transplantation. In fulminant liver failure secondary to acetaminophen overdose, mtDNA in the serum was found to be 30 to 40 times higher than normal, and nonsurvivors had higher levels than survivors ${ }^{25}$; a separate study of drug-induced acute liver failure found serum mtDNA levels to be 10,000-fold higher ${ }^{26}$. Serum mtDNA of acetaminophen overdose patients with derangement in the liver enzyme alanine aminotransferase (a marker of hepatocyte damage) is significantly higher than that of overdose patients who had normal liver enzymes ${ }^{27}$, suggesting that the extent of mtDNA release into the circulation depends on the extent of hepatocyte necrosis. Similarly, extensive cardiomyocyte necrosis is found in acute myocardial infarction, which is also associated with elevated mtDNA in multiple studies $^{28-30}$ and falls after angioplasty or coronary stent insertion to restore blood flow to the damaged myocardium ${ }^{28,29}$. Patients with diabetes mellitus and coronary artery disease have higher mtDNA levels than those with diabetes but without coronary artery disease $^{31,32}$. mtDNA is also higher in acute cerebral ischaemia, caused by a reduction in cerebral blood flow by embolus or local thrombosis, and plasma levels gradually drop over time after the initial tissue injury ${ }^{33}$. Interestingly, studies by the same group relating to plasma mtDNA in subarachnoid haemorrhage and spontaneous intracerebral haemorrhage found no significant difference compared with healthy controls, although both were small studies ${ }^{34,35}$. Higher mtDNA is found in the cerebrospinal fluid of patients with subarachnoid haemorrhage ${ }^{34}$ and traumatic brain injury $^{36}$ and is associated with worse clinical outcomes. Overall, in these conditions, significant mtDNA release following massive tissue or cellular injury is evident and likely contributes to the uncontrolled inflammatory response ${ }^{25}$.

\section{Chronic inflammatory and immune-mediated diseases}

The role for mtDNA in immune-mediated inflammatory diseases, unlike conditions relating to injury, is now also emerging. In rheumatoid arthritis, a chronic relapsing autoimmune condition affecting the joints, mtDNA was present in the plasma and synovial fluid of most patients but undetectable in healthy controls ${ }^{37}$. Similarly, higher plasma mtDNA is found in granulomatosis with polyangiitis, an autoimmune disease whose features include necrotising granulomatous inflammation and vasculitis ${ }^{38}$. Systemic lupus erythematosus (SLE) is a multi-organ autoimmune disease with hallmarks including excessive type I interferon (IFN) and antibodies against nucleic acids. Caielli et al. explored the potential pathogenic importance of oxidised mtDNA in $\mathrm{SLE}^{39}$. They showed that there is a defect in mitochondrial clearance that leads to abnormal extrusion of oxidised mtDNA, which triggers a subsequent interferogenic 
Table 1. Circulating mitochondrial DNA in human disease.

\begin{tabular}{|c|c|c|c|c|}
\hline $\begin{array}{l}\text { Disease } \\
\text { category }\end{array}$ & Disease & $\begin{array}{l}\text { Blood } \\
\text { fraction }\end{array}$ & Finding & Reference(s) \\
\hline \multirow[t]{9}{*}{ Trauma } & Trauma & Plasma & $\begin{array}{l}\text { High mtDNA levels in trauma compared with HCs and correlated } \\
\text { with injury severity }\end{array}$ & 7 \\
\hline & Trauma & Plasma & High mtDNA levels in trauma & 8,9 \\
\hline & Trauma with MODS & Plasma & $\begin{array}{l}\text { Higher levels of mtDNA had higher relative risk for mortality } \\
\text { Higher levels of mtDNA in those with SIRS/MODS compared with } \\
\text { those without }\end{array}$ & 10 \\
\hline & $\begin{array}{l}\text { Trauma and severe } \\
\text { sepsis }\end{array}$ & Plasma & $\begin{array}{l}\text { mtDNA higher in patients with trauma compared with } \mathrm{HCs} \text { on day } \\
1 \\
\text { mtDNA correlates with injury severity scores in trauma patients } \\
\text { mtDNA higher on day } 1 \text { in non-survivors compared with survivors }\end{array}$ & 11 \\
\hline & Post-traumatic SIRS & Plasma & mtDNA is an independent predictor for post-traumatic SIRS & 12 \\
\hline & Trauma & Plasma & $\begin{array}{l}\text { mtDNA higher in trauma patients with correlation with injury } \\
\text { severity }\end{array}$ & 7 \\
\hline & $\begin{array}{l}\text { Trauma (femur } \\
\text { fracture) }\end{array}$ & Plasma & mtDNA higher in trauma patients than $\mathrm{HCs}$ & 13 \\
\hline & Trauma & Plasma & $\begin{array}{l}\text { mtDNA higher in trauma patients compared with HCs at two time } \\
\text { points (pre-hospital and day } 1 \text { ) }\end{array}$ & 14 \\
\hline & Trauma & Plasma & $\begin{array}{l}\text { mtDNA higher in trauma patients than } \mathrm{HCs} \\
\text { mtDNA higher in non-survivors compared with survivors }\end{array}$ & 15 \\
\hline \multirow[t]{8}{*}{ Sepsis } & Severe sepsis & Plasma & $\begin{array}{l}\text { mtDNA higher in patients with severe sepsis compared with HCs } \\
\text { No significant difference in mtDNA between non-survivors and } \\
\text { survivors in severe sepsis }\end{array}$ & 11 \\
\hline & $\begin{array}{l}\text { Severe sepsis in } \\
\text { the ED }\end{array}$ & Plasma & $\begin{array}{l}\text { mtDNA higher on admission in severe septic patients than in HCs } \\
\text { mtDNA is higher in non-survivors than in survivors, increases } \\
\text { initially and gradually decreases after antimicrobial therapy, and is } \\
\text { an independent predictor of fatality }\end{array}$ & 16 \\
\hline & Sepsis & Plasma & mtDNA higher in septic patients compared with HCs & 17 \\
\hline & Septic shock & Plasma & mtDNA higher in patients with septic shock & 18 \\
\hline & $\begin{array}{l}\text { Adult community- } \\
\text { acquired bacterial } \\
\text { meningitis }\end{array}$ & Plasma & $\begin{array}{l}\text { mtDNA levels were higher in patients with aseptic or bacterial } \\
\text { meningitis compared with HCs } \\
\text { mtDNA levels fall during course of admission } \\
\text { High mtDNA levels associated with poorer outcome in adult } \\
\text { community-acquired bacterial meningitis }\end{array}$ & 19 \\
\hline & Infectious SIRS & Plasma & mtDNA higher in septic patients compared with HCs & 20 \\
\hline & Paediatric sepsis & Plasma & $\begin{array}{l}\text { mtDNA higher in septic patients compared with critically ill non- } \\
\text { septic and HC patients }\end{array}$ & 21 \\
\hline & $\begin{array}{l}\text { Severe sepsis in } \\
\text { the ED }\end{array}$ & Plasma & $\begin{array}{l}\text { No significant difference in mtDNA between sepsis and HC } \\
\text { cohorts }\end{array}$ & 22 \\
\hline \multirow{3}{*}{$\begin{array}{l}\text { Critically ill } \\
\text { patients }\end{array}$} & ICU patients & Plasma & Increased mtDNA levels associated with medical ICU mortality & 23 \\
\hline & $\begin{array}{l}\text { Critically ill patients } \\
\text { (in the ICU) }\end{array}$ & Plasma & $\begin{array}{l}\text { Patients with highest quartile of mtDNA in plasma had higher risk } \\
\text { of dying } \\
\text { When stratified by TLR9 expression, only patients with high } \\
\text { expression of TLR9 had an association with mortality and mtDNA } \\
\text { level }\end{array}$ & 24 \\
\hline & $\begin{array}{l}\text { Out-of-hospital } \\
\text { cardiac arrest }\end{array}$ & Plasma & Significantly higher levels in non-survivors than in survivors & $56^{a}$ \\
\hline Liver failure & $\begin{array}{l}\text { Acetaminophen- } \\
\text { induced acute liver } \\
\text { failure }\end{array}$ & Serum & $\begin{array}{l}\text { mtDNA higher in acetaminophen-induced acute liver failure } \\
\text { patients compared with HCs } \\
\text { mtDNA higher in non-survivors compared with survivors }\end{array}$ & 25 \\
\hline
\end{tabular}




\begin{tabular}{|c|c|c|c|c|}
\hline \multirow[t]{3}{*}{$\begin{array}{l}\text { Disease } \\
\text { category }\end{array}$} & Disease & $\begin{array}{l}\text { Blood } \\
\text { fraction }\end{array}$ & Finding & Reference(s) \\
\hline & $\begin{array}{l}\text { Acetaminophen- } \\
\text { induced acute liver } \\
\text { injury }\end{array}$ & Plasma & $\begin{array}{l}\text { mtDNA higher in patients with acetaminophen overdose with } \\
\text { abnormal liver function tests compared with HCs and those with } \\
\text { acetaminophen overdose but normal liver function tests }\end{array}$ & 27 \\
\hline & $\begin{array}{l}\text { Fulminant liver } \\
\text { failure }\end{array}$ & Serum & Higher during acute liver injury & 26 \\
\hline \multirow[t]{6}{*}{ Heart disease } & AMl & Plasma & $\begin{array}{l}\text { Significantly higher mtDNA in ST elevation myocardial infarction } \\
\text { patients than in stable angina pectoris patients (reducing rapidly } \\
\text { to similar levels } 3 \text { days after } \mathrm{PCI} \text { ) }\end{array}$ & 28 \\
\hline & AMI & Plasma & $\begin{array}{l}\text { Significantly higher levels in AMI patients compared with HCs } \\
\text { Levels dropped to normal immediately after PCl }\end{array}$ & 29 \\
\hline & AMI & Plasma & $\begin{array}{l}\text { Significantly higher levels in acute AMI patients compared with } \\
\text { HCs on admission }\end{array}$ & 30 \\
\hline & T2DM with CAD & Plasma & $\begin{array}{l}\text { Significantly elevated levels in T2DM compared with HCs } \\
\text { Higher levels in those with diabetes mellitus and CAD compared } \\
\text { with those without CAD } \\
\text { mtDNA levels correlated with C-reactive protein in patients with } \\
\text { CAD }\end{array}$ & 31 \\
\hline & T2DM with CAD & Plasma & Significantly higher levels in CAD patients with T2DM & 32 \\
\hline & Heart failure & Plasma & $\begin{array}{l}\text { Higher levels of mtDNA in heart failure patients compared with } \\
\text { age- and sex-matched HCs; no association with disease severity }\end{array}$ & 110 \\
\hline \multirow[t]{3}{*}{ Stroke } & $\begin{array}{l}\text { Acute ischaemic } \\
\text { stroke }\end{array}$ & Plasma & $\begin{array}{l}\text { mtDNA levels higher in acute cerebral infarction than in } \mathrm{HCs} \\
\text { No significant difference in mtDNA between good versus poor } \\
\text { outcome cohorts }\end{array}$ & 33 \\
\hline & $\begin{array}{l}\text { Subarachnoid } \\
\text { haemorrhage }\end{array}$ & Plasma & $\begin{array}{l}\text { No significant difference in mtDNA between subarachnoid } \\
\text { haemorrahge and HC groups } \\
\text { Overall plasma mtDNA not a good marker of prognosis }\end{array}$ & 34 \\
\hline & $\begin{array}{l}\text { Intracerebral } \\
\text { haemorrhage }\end{array}$ & Plasma & $\begin{array}{l}\text { No significant difference in mtDNA between intracerebral } \\
\text { haemorrhage and HC groups } \\
\text { No correlation between mtDNA and disease severity }\end{array}$ & 35 \\
\hline \multirow[t]{9}{*}{ Malignancy } & Breast cancer & Plasma & $\begin{array}{l}\text { Reduced levels of mtDNA in benign or malignant breast cancer } \\
\text { compared with HCs }\end{array}$ & 111 \\
\hline & Ovarian cancer & $\begin{array}{l}\text { Plasma and } \\
\text { serum }\end{array}$ & $\begin{array}{l}\text { Plasma: significantly higher levels of mtDNA in ovarian cancer } \\
\text { group compared with HCs and ovarian benign tumour group } \\
\text { Serum: no significant difference between groups above }\end{array}$ & 112 \\
\hline & $\begin{array}{l}\text { Testicular germ cell } \\
\text { cancer }\end{array}$ & Serum & $\begin{array}{l}\text { mtDNA levels were significantly higher in patients with testicular } \\
\text { cancer than in HCs, although it did not correlate with any } \\
\text { clinicopathological variable of disease status }\end{array}$ & 113 \\
\hline & $\begin{array}{l}\text { Urological } \\
\text { malignancies }\end{array}$ & Serum & $\begin{array}{l}\text { mtDNA were significantly higher in "urological malignancies" } \\
\text { (bladder cell, renal cell, and prostate cancer) }\end{array}$ & 114 \\
\hline & Prostate cancer & Serum & $\begin{array}{l}\text { mtDNA could not distinguish between benign prostatic } \\
\text { hypertrophy and prostate cancer } \\
\text { Patients with early biochemical recurrence after radical } \\
\text { prostatectomy have higher mtDNA levels }\end{array}$ & 115 \\
\hline & Ewing's sarcoma & Serum & $\begin{array}{l}\text { mtDNA significantly lower in patients with Ewing's sarcoma } \\
\text { compared with HCs }\end{array}$ & 116 \\
\hline & Lung cancer & Serum & $\begin{array}{l}\text { mtDNA significantly higher in lung cancer patients compared } \\
\text { with those with benign lung diseases and healthy individuals and } \\
\text { closely associated with tumour, lymph node, metastasis (TNM) } \\
\text { stage }\end{array}$ & 117 \\
\hline & $\begin{array}{l}\text { Advanced prostate } \\
\text { cancer }\end{array}$ & Plasma & $\begin{array}{l}\text { mtDNA levels are elevated in advanced prostate cancer patients } \\
\text { and are associated with decreased survival }\end{array}$ & 118 \\
\hline & $\begin{array}{l}\text { Adenocarcinoma of } \\
\text { the lung in patients } \\
\text { receiving erlotinib }\end{array}$ & Plasma & $\begin{array}{l}\text { Rise in mtDNA levels in patients with partial response; drop in } \\
\text { mtDNA levels in those with progressive disease or no response } \\
\text { No correlation with progression-free survival }\end{array}$ & 119 \\
\hline
\end{tabular}




\begin{tabular}{|c|c|c|c|c|}
\hline \multirow[t]{3}{*}{$\begin{array}{l}\text { Disease } \\
\text { category }\end{array}$} & Disease & $\begin{array}{l}\text { Blood } \\
\text { fraction }\end{array}$ & Finding & Reference(s) \\
\hline & $\begin{array}{l}\text { Exposure to } \\
\text { carcinogenic } \\
\text { halo-alkane-based } \\
\text { pesticides }\end{array}$ & Serum & $\begin{array}{l}\text { Exposure to these carcinogens was significantly associated with } \\
\text { elevated serum levels of circulating mtDNA (case control study) }\end{array}$ & 120 \\
\hline & $\begin{array}{l}\text { Renal cell } \\
\text { carcinoma }\end{array}$ & Plasma & $\begin{array}{l}\text { Higher levels in metastatic compared with non-metastatic patients } \\
\text { and controls }\end{array}$ & 121 \\
\hline \multirow[t]{3}{*}{ HIV } & HIV & Plasma & $\begin{array}{l}\text { Higher levels in acute HIV infection, late presenters compared with } \\
\text { long-term non-progressors and HCs } \\
\text { Also correlated with viral load }\end{array}$ & 122 \\
\hline & $\begin{array}{l}\text { Lipodystrophy } \\
\text { in HIV patients } \\
\text { treated with highly } \\
\text { active anti-retroviral } \\
\text { therapy }\end{array}$ & Plasma & $\begin{array}{l}\text { Significantly higher levels in HIV-infected versus non-infected } \\
\text { individuals } \\
\text { Significantly higher levels in those with lipodystrophy compared } \\
\text { with those without lipodystrophy at month } 24\end{array}$ & 123 \\
\hline & HIV & Plasma & No significant association between HIV disease status and mtDNA & 124 \\
\hline \multirow{2}{*}{$\begin{array}{l}\text { Inflammatory } \\
\text { autoimmune } \\
\text { conditions }\end{array}$} & Rheumatoid arthritis & Plasma & $\begin{array}{l}\text { Higher percentage of detectable levels in rheumatoid arthritis } \\
\text { patients compared with controls }\end{array}$ & $37^{\mathrm{b}}$ \\
\hline & $\begin{array}{l}\text { Granulomatosis with } \\
\text { polyangiitis }\end{array}$ & Serum & $\begin{array}{l}\text { Significantly higher levels in granulomatosis with polyangiitis } \\
\text { patients compared with controls }\end{array}$ & 38 \\
\hline \multirow{5}{*}{$\begin{array}{l}\text { Age and } \\
\text { exercise }\end{array}$} & Age & Plasma & mtDNA levels increased gradually after the fifth decade of life & 125 \\
\hline & Age & Plasma & No association with age but mtDNA associated with HLA-DR & 126 \\
\hline & Aging and "frailty" & Plasma & $\begin{array}{l}\text { Aging: no difference in mtDNA between younger and older } \\
\text { subjects } \\
\text { Frailty: mtDNA copy number directly correlated with frailty score }\end{array}$ & 127 \\
\hline & Exercise & Plasma & Reduced mtDNA in response to exercise & 128 \\
\hline & $\begin{array}{l}\text { Male volleyball } \\
\text { players }\end{array}$ & Plasma & $\begin{array}{l}\text { Lower levels in professional volleyball players compared with } \\
\text { healthy non-athlete controls }\end{array}$ & 129 \\
\hline \multirow[t]{9}{*}{ Miscellaneous } & $\begin{array}{l}\text { Corrosive injury } \\
\text { (gastrointestinal } \\
\text { ingestion) }\end{array}$ & Plasma & $\begin{array}{l}\text { Significantly higher mtDNA in mortality group versus survival } \\
\text { group at presentation and after } \\
12 \text { hours }\end{array}$ & 130 \\
\hline & $\begin{array}{l}\text { Pulmonary } \\
\text { embolism }\end{array}$ & Plasma & Predictor of 15-day mortality & $131^{\mathrm{c}}$ \\
\hline & Autism & Serum & $\begin{array}{l}\text { Significantly higher mtDNA in young autistic children compared } \\
\text { with HCs }\end{array}$ & 132 \\
\hline & Haemodialysis & Plasma & $\begin{array}{l}\text { Significantly higher levels in maintenance haemodialysis patients } \\
\text { compared with } \mathrm{HCs}\end{array}$ & 133 \\
\hline & $\begin{array}{l}\text { End-stage renal } \\
\text { failure in Han } \\
\text { population }\end{array}$ & Plasma & End-stage renal failure patients had higher mtDNA copy number & 134 \\
\hline & Bipolar disorder & Serum & $\begin{array}{l}\text { No difference between bipolar disorder and HC groups } \\
\text { Higher levels in bipolar disorder group compared with sepsis }\end{array}$ & 135 \\
\hline & $\begin{array}{l}\text { Low levels of } \\
\text { ionising radiation }\end{array}$ & Serum & $\begin{array}{l}\text { Higher levels in interventional cardiologists exposed to low levels } \\
\text { of ionising radiation compared with controls }\end{array}$ & 136 \\
\hline & Friedreich's ataxia & Plasma & $\begin{array}{l}\text { Significantly reduced mtDNA in Friedreich's ataxia patients } \\
\text { compared with HCs }\end{array}$ & 137 \\
\hline & $\begin{array}{l}\text { Non-haemolytic } \\
\text { transfusion reaction }\end{array}$ & $\begin{array}{l}\text { Platelet } \\
\text { concentrates }\end{array}$ & $\begin{array}{l}\text { Higher mtDNA copy number in non-haemolytic transfusion } \\
\text { reaction platelet concentrate versus normal platelet concentrate }\end{array}$ & 138 \\
\hline
\end{tabular}

This table lists studies reporting mitochondrial DNA ( $m$ tDNA) analysed by polymerase chain reaction (PCR) on serum or plasma-that is, circulating as a

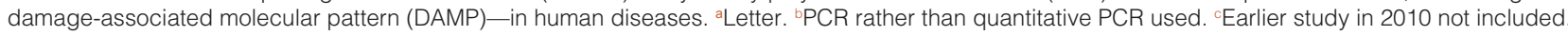
$\mathrm{AMI}$, acute myocardial infarction; CAD, coronary artery disease; ED, emergency department; HC, healthy control; HIV, human immunodeficiency virus; HLADR, human leukocyte antigen-antigen D related; ICU, intensive care unit; MODS, multiple organ dysfunction syndrome; PCI, percutaneous coronary intervention; SIRS, systemic inflammatory response syndrome; T2DM, type 2 diabetes mellitus; TLR9, Toll-like receptor 9. 


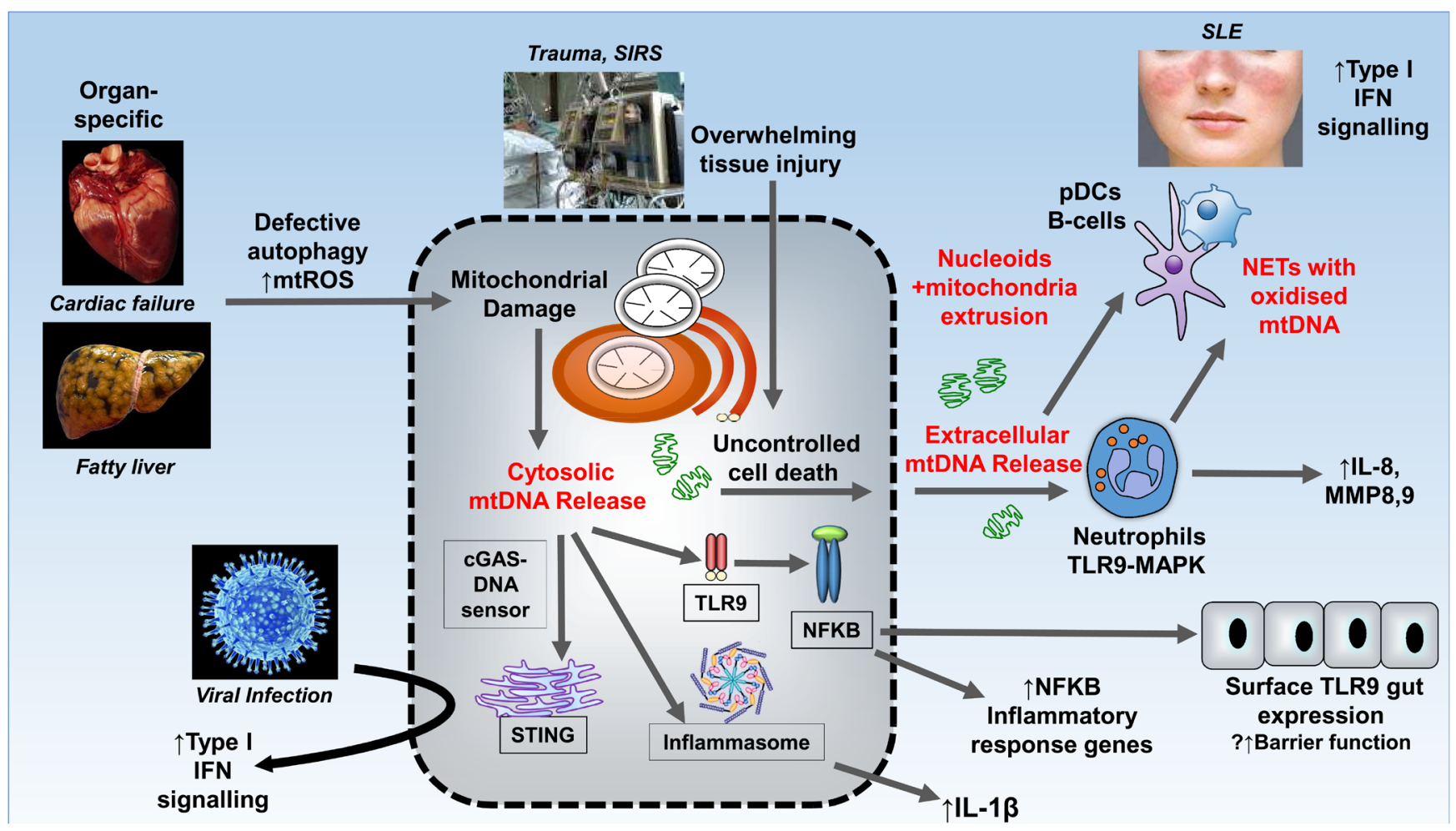

Figure 1. The contribution of mitochondrial DNA to disease pathogenesis. Medical conditions are in italics. Where and how mitochondria are released are indicated in red. Box in dotted line frames mitochondrial DNA (mtDNA) sensor target. cGAS, cyclic GMP-AMP synthetase; IFN, interferon; IL, interleukin; MAPK, mitogen-activated protein kinase; MMP, matrix metalloproteinase; mtROS, mitochondria-derived reactive oxygen species; NET, neutrophil extracellular trap; NFאB, nuclear factor kappa B; pDC, plasmacytoid dendritic cell; SIRS, systemic inflammatory response syndrome; SLE, systemic lupus erythematosus; STING, stimulator of interferon genes; TLR9, Toll-like receptor 9.

response. Elevated anti-mtDNA antibodies were found in a separate study of SLE, particularly in lupus nephritis, where levels correlated with the lupus nephritis activity index better than anti-double-stranded DNA (anti-dsDNA) antibody levels $\operatorname{did}^{40}$. In a further study of SLE, neutrophil extracellular traps (NETs) released from the inflammatory subset of low-density granulocyte were highly enriched in mtDNA compared with NETs from healthy control neutrophils ${ }^{41}$. NETs are networks of extracellular fibres that are primarily composed of DNA and that are strikingly expelled following a form of neutrophil cell death (NETosis) with an aim to control pathogens; however, this study demonstrates that mtDNA-enriched NETs are pro-inflammatory in nature. Similar findings are reported in chronic granulomatous disease in this study. Higher levels of mtDNA have been found in the chronic inflammatory states of HIV (although not in all studies), end-stage renal failure, and diabetes mellitus (Table 1). In obese individuals with steatohepatitis, mitochondria enclosed in microparticles can also be detected in plasma ${ }^{42}$. These findings suggest that mtDNA, otherwise a "self-signal", may be an active component in the aberrant immune or inflammatory response in chronic diseases and in autoimmunity.

\section{mtDNA contributes to inflammatory response}

mtDNA was first directly implicated as a key factor in the development of inflammatory pathology over a decade ago when intraarticular injection of oxidised mtDNA, but not nuclear DNA, triggered inflammatory arthritis in mice ${ }^{43}$. There are now numerous studies using in vivo injection of mtDNA to provoke local or systemic inflammation or both ${ }^{9,4-46}$. Moreover, there are now several in vivo studies to show that genetic deletion or pharmacologic interference of these pathways reduces the inflammatory effect of mtDNA (as will be discussed in the next section). Hence, it is clear that mtDNA release is not an epiphenomenon but directly contributes to the genesis of inflammation (Figure 1). Current evidence shows that mtDNA-mediated inflammation is predominantly driven by the Toll-like receptor 9 (TLR9), inflammasome, and, more recently, stimulator of interferon genes (STING) pathways.

\section{Toll-like receptor 9}

TLR9 is located in the endoplasmic reticulum (ER) of various immune cells and translocates to the endosome upon sensing of hypomethylated DNA with CpG motifs, such as bacterial DNA ${ }^{47,48}$. 
Given its high frequency of unmethylated $\mathrm{CpG}$ dinucleotide repeats, it is postulated that mtDNA mediates inflammation dependent on the TLR9 pathway and potentially exerts a similar effect as on bacterial CpG. TLR9 recognises a variety of types of oligodeoxynucleotides (ODNs); for example, class A ODNs preferentially activate plasmacytoid dendritic cells whilst class B CpG ODNs activate $\mathrm{B}$ cells ${ }^{49}$. Some of our understanding of how mtDNA may interact with TLR9 is extrapolated from work with class A ODNs, although they do not necessarily have the same effect. After activation of TLR9 by CpG DNA, inflammatory cytokine induction and Th1 immune responses occur ${ }^{50}$ and TLR9 is necessary in CpG DNA-driven responses ${ }^{51}$. TLR9 ligands can preferentially activate downstream pathways, including pro-inflammatory nuclear factor kappa B (NFKB), nucleotide-bindingdomain and leucine-rich repeat (NLR) pyrin domain containing 3 (NLRP3) inflammasomes, and interferon regulatory factor (IRF)-dependent type 1 IFN, which can upregulate IL-1 receptor antagonist ${ }^{52,53}$.

Most tissue injury models show better outcomes when the tlr 9 gene is deleted. Wei et al. recently observed that $t l r 9^{-/-}$mice have improved survival outcome in a necrotic lung model of cationic nanocarrier-induced necrosis and mtDNA release in vivo ${ }^{54}$. Furthermore, the pulmonary inflammation seen after injection of mtDNA was significantly reduced in $t / r 9^{-/-}$and $M y D 88^{-/-}$mice, underlining the importance of the TLR9-MyD88 pathway $^{54}$. Intravenous injection of mitochondrial debris with substantial amounts of mtDNA into mice induced a systemic inflammatory response in wild-type mice that was significantly attenuated in $\operatorname{tr} 9^{-/-}$mice ${ }^{45}$. $T \operatorname{lr} 9^{-/-}$mice also have better survival compared with wild-type counterparts in severe renal ischaemia reperfusion injury with associated decreased circulating $\mathrm{mtDNA}^{55}$. A similar protective effect is seen in $t \operatorname{tr} 9^{-/-}$ mice with acute acetaminophen overdose with observed lower serum mtDNA and an absence of lung inflammation in contrast to the findings of wild-type mice ${ }^{26}$. Nevertheless, the reduction in mtDNA in $t \operatorname{tr} 9^{-/-}$mice is intriguing and could be explained by the reduced inflammation with lower resultant cellular necrosis. Alternatively, it is possible that TLR9 is somehow involved in mtDNA release into the extracellular circulation. In a recent study using a murine model of non-alcoholic steatohepatitis (NASH), mtDNA from NASH hepatocytes resulted in greater activation of TLR9 than did mtDNA from control livers ${ }^{42}$. This suggests that mtDNA that is selectively modified during pathologic disease processes can augment the ensuing inflammatory response. Similarly, the level of TLR9 expression (due to various factors) appears to be important. In those with high mtDNA levels, higher TLR9 expression is associated with increased mortality in the intensive care unit (ICU), as discussed earlier ${ }^{56}$.

Neutrophils have received the most attention in studies on mtDNA-TLR9 signalling in several different inflammatory settings. Zhang et al. found that mtDNA activates neutrophil p38 mitogen-activated protein kinase (MAPK) through TLR9 with release of matrix metalloproteinase 8 (MMP8) and MMP9 ${ }^{8,9}$, a finding confirmed in a study in which phosphorylated p38 and MMP9 increased after mtDNA treatment of neutrophils ${ }^{57}$. A separate study reported similar findings where pre-treatment with TLR9 inhibitor ODN2088 inhibited the activation of p38 MAPK and release of MMP $^{54}$. Gu et al. also found that intratracheal administration of
mtDNA provokes lung inflammation through TLR9-p38 MAPK $^{58}$. Hip fracture in rats resulted in mtDNA release into the circulation as well as higher TLR9 and NFKB p65 activation and subsequent lung injury ${ }^{46}$. The role of other MAPKs such as extracellular signal -regulated kinases (ERKs) and c-Jun N-terminal kinases (JNKs) remains unclear and, to our knowledge, unexamined in this context. These data suggest a pathway where mtDNA activates neutrophils through TLR9 binding and activation of the MAPK pathway with subsequent MMP8 and MMP9 release (Figure 1).

When mtDNA is considered vis-à-vis the site and location of TLR9 receptor, mtDNA must be either displaced from whole mitochondria and moved into the cytosol or, when extracellular, internalised by some mechanism(s) to act on endosomal TLR9. The endosomal location of TLR9 is most likely a mechanism to avoid unwanted activation $^{59}$. It is unclear how extracellular mtDNA is internalised, but possibilities include endocytosis, transmembrane diffusion, phagocytosis, and receptor-mediated endocytosis ${ }^{60}$. Transmembrane diffusion is unlikely because of the highly (negatively) charged nature of DNA, which makes it difficult to pass through the cellular membrane. A recent study found that monocytederived macrophages can take up whole mitochondria released from necroptosis, suggesting that phagocytosis could be a relevant mechanism $^{61}$. The macrophage has a clear role in resolving inflammation by clearing up cellular debris and apoptotic bodies by phagocytosis. When mitochondria are not cleared during non-apoptotic cell death, the macrophage may phagocytose cellular corpses with mtDNA still abundantly present. Typically, apoptotic corpses can suppress the transcription of pro-inflammatory cytokine genes, promote the secretion of anti-inflammatory cytokines by phagocytes, and cause antigen-presenting cells to present dead cell antigen in a manner that promotes immunological tolerance (reviewed by Zitvogel et $a l .{ }^{62}$ ). It will be of interest to consider the fate of mtDNA when macrophages or dendritic cells phagocytose cellular corpses with mtDNA. Does this clear the mtDNA or does it regulate subsequent functions (for example, immune responsiveness) in these cell types? This has yet to be studied in detail. It is also possible that binding to additional cofactors facilitates the internalisation into immune cells, and, in this instance, high-mobility group box 1 (HMGB1) and receptor for advanced glycation end products (RAGE) have been implicated ${ }^{63}$. In this study, HMGB $1-C p G$ (class A) complexes resulted in TLR9/RAGE association and recruitment of MyD88 in B cells ${ }^{63}$. Here, RAGE was visualised as associating with the DNA and was internalised with some sequestered in endosome-like structures. However, this possible mechanism requires further investigation. It has also been proposed that activation of autoreactive $\mathrm{B}$ cells by $\mathrm{CpG}$ DNA occurs after B-cell receptor engagement, leading to the delivery of $\mathrm{CpG}$ DNA to endosomal TLR9 ${ }^{64}$.

Although nucleic acid-sensing TLRs on immune cells are found mainly within cells, cell surface expression has also been described. Via flow cytometry, TLR9 has been detected on the surface of resting B lymphocytes ${ }^{65,66}$ and peripheral blood mononuclear cells ${ }^{67,68}$. One functional ex vivo study found primary human and mouse TLR9 surface expression in neutrophils, which are upregulated by a variety of stimuli, including TLR9 agonists ${ }^{69}$. However, it remains unclear whether TLR9 is able to signal from the cell 
surface. In other cell types, TLR9 is also expressed on the cell surface. For example, TLR9 is expressed on both the apical and the basolateral membranes of intestinal epithelial cells, although NFKB is activated only via basolateral stimulation of $\mathrm{CpG}$ ligands ${ }^{70,71}$. This is relevant at the gut mucosal interface, as this limits the extent of TLR9 activation at the apical surface, which is in contact with a luminal milieu rich with bacterial DNA. Hence, compromised intestinal barrier integrity and translocation of bacterial $\mathrm{CpG}$ from the lumen during gut pathology will lead to basolateral stimulation in this context. Whether mtDNA has a different propensity compared with bacterial CpG to trigger TLR9 depending on epithelial site has not been studied.

\section{The inflammasome}

The inflammasomes are targets of mtDNA leading to cleavage and activation of caspase- 1 and downstream maturation of interleukin-1 $\beta$ (IL-1 $\beta$ ) and IL-18 $8^{72}$. Here, it is the cytosolic release of mtDNA that exerts the dominant effect on inflammasome activation. Of the several inflammasomes described, the NLRP3 inflammasome is the best characterised in this regard. Nakahira et al. showed that depletion of mtDNA reduced IL- $1 \beta$ secretion in macrophages following treatment with known inflammasome triggers lipopolysaccharide (LPS) and $\mathrm{ATP}^{73}$. Of interest, mitochondria-derived reactive oxygen species (mtROS) is a further key mediator in this process. Pharmacologic induction of mtROS correlates with higher secretion of active IL-1 $\beta$ in an NLRP3- and caspase-1-dependent manner, and treatment with mtROS scavengers suppresses this effect $^{74}$. The requirement for mtROS in NLRP3 activation has been confirmed by other studies ${ }^{73,75-77}$ and may be explained by its oxidising effects on mtDNA. Shimada et al. showed that it is the oxidised form of mtDNA that confers the inflammatogenic potential to $\mathrm{mtDNA}^{75}$. mtROS enhances not only the oxidative process but also the cytosolic translocation of oxidised mtDNA that then binds directly to NLRP $3^{75}$. Non-oxidised mtDNA is insufficient to activate the NLRP3 inflammasome, although it may stimulate IL- $1 \beta$ production via other inflammasomes such as the absent in melanoma $2(\mathrm{AIM} 2)^{78}$. Interestingly, genetic deletion of NLRP3 and caspase- 1 results in less mtDNA release ${ }^{73,77}$. This suggests a positive-feedback loop, in which activation of the NLRP3 inflammasome by oxidised mtDNA further promotes mtDNA release. The overwhelming or persisting (or both) ROS production by inflammatory cells, for example, is known to damage macromolecules (DNA as well as RNA, lipids, carbohydrates, and proteins) of the surrounding cells. Activated neutrophils produce large amounts of ROS as part of their essential role in host defense ${ }^{79}$. Hence, this is a likely major contributory factor to mtDNA damage once the inflammatory process is triggered.

Other factors controlling mitochondria-mediated NLRP3 activation are also relevant. For example, defective autophagy increases caspase- 1 activation, IL- $1 \beta$ and IL-18 production, and cytosolic mtDNA translocation in LPS- and ATP-primed macrophages ${ }^{76}$. Pharmacological inhibition of mitophagy/autophagy in human macrophages results in the accumulation of damaged mitochondria, ROS generation and IL-1 $\beta$ secretion ${ }^{74}$, and increased NLRP3 expression in the presence of LPS ${ }^{80}$. Hence, defective autophagy leads to inadequate clearance of damaged mitochondria, priming the internal cellular environment for NLRP3 activation. It is noteworthy that, given the diversity of NLRP3 activators, current literature suggests that the precise mechanism of NLRP3 activation is still under debate $^{81}$. Although the role of the inflammasome is often considered separately from TLR9 here, there is evidence that TLR/NFKB activation is a necessary priming step leading to NLRP3 upregulation and subsequent downstream signalling. NFKB-activating stimulus is required for cells to express pro-IL-1 $\beta$ and NLRP3 ${ }^{82}$. Imeada et al. showed that stimulation of TLR9 by DNA fragments during early acetaminophen-induced cell death can lead to the transcriptional activation of the IL-1 $\beta$ gene, resulting in the formation of pro-IL$1 \beta^{83}$. Using the acetaminophen hepatotoxicity model, they showed that NLRP3 deletion and related inflammasome components ASC and Caspase-1 were protective against induced liver failure ${ }^{83}$. A further study, however, did not show any effect of NLRP3 deletion on the outcomes of acetaminophen-induced liver failure ${ }^{84}$. Hence, in the context of liver necrosis, the role for NLRP3 inflammasome remains controversial.

\section{STING pathway}

The role of mtDNA in innate immunity through the STING pathway has also been a focus of recent studies. STING is a cytosolic protein anchored to the $\mathrm{ER}^{85}$. STING can be activated either by direct association with dsDNA or by cyclic dinucleotides, which can be derived from intracellular bacteria or viruses or produced by a DNA sensor, cyclic GMP-AMP (cGAMP) synthetase (cGAS) ${ }^{86}$. This, in turn, activates IRF3, which ultimately translocates to the nucleus and transcribes type I IFN genes, and also the NFאB pathway ${ }^{85}$.

Two independent groups recently discovered that the STINGmediated IFN response can also be activated by $\mathrm{mtDNA}^{87,88}$. They first observed that deficiency of apoptotic caspases (3, 7, and 9) resulted in upregulation of type I IFN genes. This response was dependent on $\mathrm{Bak} / \mathrm{Bax}$, pro-apoptotic proteins responsible for mitochondrial outer membrane permeabilisation leading to mtDNA release, and the release of cytochrome $\mathrm{C}$, which activates the intrinsic apoptotic pathway. Typically, apoptosis is considered immunologic-silent; for example, it does not trigger an inflammatory response. However, these studies demonstrated that, when caspases (9 and 3/7) responsible for the completion of apoptotic process are inhibited or deleted, cytosolic mtDNA goes on to activate cGAS/STING-mediated type I IFN signalling ${ }^{87,88}$. Hence, these caspases serve as a "brake" on the mtDNA-inflammatory effect during cell death. mtDNA released during cell death has been previously reported to provide a second signal that cooperates with an additional inflammatory signal (for example, LPS) to activate the NLRP3 inflammasome and induce IL-1 $\beta$ production in murine macrophages ${ }^{75}$. Further evidence of an mtDNA role in STINGmediated IFN responses comes from West et al. ${ }^{89}$. Here, partial deficiency of the mtDNA-binding protein mitochondrial transcription factor A (TFAM) was associated with increased concentrations of cytosolic mtDNA and enhanced type I IFN response, which was attenuated by knockdown of components of the STING pathway.

Aberrant mtDNA-STING signalling has also been implicated in human inflammatory diseases, such as SLE. As discussed earlier, Lood et al. showed that treatment of human neutrophils with SLEabundant ribonucleoprotein immune complexes induces mtROS, mtDNA oxidation, and translocation of the mitochondria to the 
plasma membrane ${ }^{41}$. Oxidised mtDNA is then released extracellularly as a component of NETs. Transfection of NET-derived mtDNA results in expression of IFN- $\beta$ in human peripheral mononuclear cells. Systemic injection of oxidised mtDNA increases IFN-stimulated gene expression in the spleen of wild-type but not STING-deficient mice. Similar to inflammasomes, uncontrolled mtROS production promoting cytosolic mtDNA release is important in STING activation and potentially in the case of autoimmunity. These studies highlight the importance of the innate cellular functions to handle mtDNA release during the initiation of cell death, which ultimately will decide whether the ensuing fate will be that of a silent or inflammatory outcome.

\section{Mechanisms for mtDNA release}

Two levels of mtDNA release-cytosolic and then extracellular -are critically important steps (Figure 1). In the former, the mechanism of release of mtDNA from mitochondria relies on the opening of mitochondrial permeability transition (MPT) pores in the inner mitochondrial membrane ${ }^{90}$. Inhibition of pore opening with cyclosporine A resulted in lower mtDNA in the cytosol after stimulation with LPS and ATP ${ }^{73}$. Ding et al. showed that the induction of ROS using oxidised low-density lipoprotein (ox-LDL) increased mtDNA leakage into the cytosol in a dose-dependent manner, and this effect was ameliorated with blockade of the ox-LDL receptor or a ROS inhibitor ${ }^{91}$.

In terms of extracellular release, cellular stress and necrosis are primary factors in the non-discriminant liberation of a host of mitochondrial components such as mtDNA, N-formyl peptides, ATP, TFAM, and mitochondrial lipids. These mitochondrial constituents also exert their respective effects, which are wide-ranging, on key inflammatory pathways (extensively reviewed by Nakahira et al.$^{81}$ ). Aside from this non-selective release after uncontrolled cell death, several studies have suggested additional mechanisms such as necroptosis (or programmed necrosis) ${ }^{92}$. Blood transfusion-induced endothelial necroptosis was recently found to increase extracellular mtDNA as a potential mechanism to explain transfusion-related lung injury ${ }^{93}$. A recent study suggested that, during necroptosis, mitochondria were released before plasma membrane rupture and then phagocytosed by monocyte-derived macrophages or dendritic cells, triggering an inflammatory response as shown by cytokine production and cell maturation, respectively ${ }^{61}$. Thus, ingestion of intact mitochondria may represent a distinct uptake mechanism following necroptosis. In a separate study, platelets were also found to be a source for free extracellular mitochondria release and then to act as an endogenous substrate for bactericidal secreted phospholipase $\mathrm{A}_{2}$ IIA ( $\mathrm{SPLA}_{2}$-IIA) leading to mitochondrial membrane hydrolysis, loss of mitochondrial structural integrity, and mtDNA release $^{94}$. Intriguingly, Xin et al. found lower levels of mtROS production when metformin was added to activated platelets, and this was associated with decreased extracellular mtDNA release ${ }^{95}$. The authors found lower complex I activity of the platelet mitochondrial respiratory chain and suggested this as a mechanism for the observed suppressed mitochondrial dysfunction.

Whether there is an active element in mtDNA release is an interesting point of consideration. Active cellular transfer of mitochondria from stromal cells to rescue stricken lung alveoli cells in acute lung injury has been demonstrated ${ }^{96}$. Extracellular vesicles are important modes of intercellular communication and comprise exosomes (endosomal) and microvesicles (plasma membrane-derived) and are directed by exocytosis. Both chromosomal DNA ${ }^{97,98}$ and mtDNA ${ }^{99,100}$ have been observed in extracellular vesicles; it has been suggested that the transfer of altered mtDNA between cells may play a role in Alzheimer's disease and skeletal muscle diseases ${ }^{99,100}$. As described earlier, in patients with NASH, a greater percentage of mitochondria was found inside extracellular microparticles and a higher percentage of microparticles contained mitochondria compared with lean subjects ${ }^{42}$. Furthermore, subjects with NASH had a higher level of oxidised mtDNA in microparticles. Further clarification is required on the concentration and significance of mtDNA in extracellular vesicles and whether this has different immunostimulatory effects compared with cell-free or surface-bound mtDNA. As previously mentioned, the pro-inflammatory effects of mtDNA are dependent on its oxidisation $^{75,101}$. The highly oxidative extracellular milieu at sites of tissue inflammation in patients with chronic inflammatory disease may overwhelm anti-oxidant systems, further potentiating the inflammatory potential of DAMPs such as mtDNA ${ }^{5}$.

\section{mtDNA degradation and clearance}

Several well-described clearance mechanisms limit the proinflammatory nature of mtDNA. Autophagy as discussed earlier is important ${ }^{102}$. Defective autophagy has been implicated in several chronic inflammatory human diseases, including Crohn's disease $^{103}$. A proportion of circulating DNA in the bloodstream appears to cross the kidney barrier and be excreted in the urine ${ }^{104}$. Indeed, mtDNA has been detected in the urine at elevated levels in patients with progressive acute kidney injury ${ }^{105}$. This may be due to the inflammatory state associated with this condition, the increased clearance with a disturbed kidney barrier, or both. Another possible mechanism of mtDNA clearance is phagocytosis by macrophages in a manner similar to the ingestion of the structurally similar bacterial DNA ${ }^{106}$. As described earlier, the outcome of phagocytosis of intact mitochondria may be pro- rather than anti-inflammatory; these divergent effects may also be dependent on the phenotype of the phagocytosing cells (for example, inflammatory versus proresolution macrophages/monocytes, neutrophils, and red blood

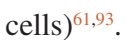

In general, non-host DNA in the circulation is digested in part by circulating nucleases, and mtDNA may be affected by a similar mechanism ${ }^{107}$. Intracellularly, DNases found in the autophagolysosome play a vital role in degrading mtDNA ${ }^{102,108}$. Oka et al. showed that cardiac-specific deletion of DNase II resulted in mtDNA accumulation in cardiomyocytes and the development of heart failure ${ }^{102}$. In human umbilical vein endothelial cells, lysosomal DNases protect cells against inflammation from mtDNA damage induced by ox-LDL ${ }^{91}$. Here, small interfering RNA (siRNA) knockdown of DNase II amplifies the mtDNA-TLR9-mediated inflammatory response $^{91}$. It is unclear whether nucleases have a similar action on mtDNA in the extracellular space or are relevant in the physiological setting, especially when mtDNA is present in microvesicles or housed within intact mitochondria, which protect against 
DNase II. Intriguingly, DNase pre-treatment abolished renal mitochondrial injury that was observed after injection of mitochondrial debris (including mtDNA) in mice ${ }^{45}$. However, the precise role of DNase and its effect on the immunostimulatory effects of mtDNA is likely to be more complex, as illustrated by a recent study which showed that DNase II was required for TLR9 activation by bacterial genomic DNA ${ }^{109}$.

\section{Conclusions: translational opportunities for mtDNA- mediated inflammation}

mtDNA contributes to inflammation at multiple levels when tissue or cellular homeostasis is perturbed. Damaged mtDNA released into the cytosol has a functional short-range effect on immediate "alarm" systems such as the inflammasome and NFKB. Uncontrolled release of mtDNA into the circulation in conditions with significant tissue injury generates a more systemic effect whilst de-regulation of local mitochondrial homeostatic mechanisms such as autophagy or mtROS detoxification contributes to organspecific pathology as observed in the heart and liver. Failure of such mechanisms may also give rise to a more wide-ranging consequence (for example, in autoimmune diseases such as SLE).

Our review shows that mtDNA-mediated inflammation is important and relevant to many human inflammatory diseases. However, this remains an underexplored field and more insights will likely emerge in the near future. The current evidence offers a rich realm of translational opportunities to target mtDNA-mediated inflammation. There are many plausible approaches, which include targeting cytosolic mtDNA release (for example, directly at MPT using cyclosporine or by specific mitochondrial anti-oxidant strategies, such as MitoQ10 ${ }_{10}$ to reduce mtROS), augmenting clearance (for example, using autophagy activators or correcting factors leading to impaired autophagy), diverting the cellular response following mitochondrial damage (for example, induction of pro-apoptotic caspases), and reducing the inflammatory potential of mtDNA (for example, DNases to digest NET-bound mtDNA and reducing oxidation of mtDNA).
Given that mtDNA can be measured and used as a biomarker, it offers a unique opportunity to stratify and identify individuals who may benefit from specific therapeutic targeting of downstream inflammation pathways (for example, TLR9, NLRP3, or STING pathways). As discussed earlier, there are numerous studies in sepsis, trauma, and acute single-organ injury that have already demonstrated that individuals with high mtDNA levels and TLR9 expressions have worse prognosis. Therefore, there are clear groups in which stratification is useful. However, a number of challenges exist to its implementation as a biomarker, such as the variation in which mtDNA is measured (for example, serum versus plasma, mtDNA-specific PCR primers) and reported in the literature. Standardisation of these protocols, including the identification of "normal" and "abnormal" ranges, will be important prior to clinical use. Furthermore, many studies have failed to include clinically relevant predictive statistics; further studies reporting such statistics in a variety of inflammatory conditions are required.

In conclusion, multiple lines of data show that innate responses to mtDNA, which is similar to and evolutionarily derived from bacteria, are hard-wired into our biology and drive the development inflammation with pathologic consequences in many diseases.

\section{Competing interests}

The authors declare that they have no competing interests.

\section{Grant information}

This work was supported by Medical Research Council grant G0701898, Crohn's and Colitis UK M16-1, ECCO IBD Investigator's Award 2010, Chief Scientist Office ETM/75 award (to G-TH); Edinburgh GI Trustees Grant (2014) (to RKB); Medical Research Society UK Vac-982-2016 (to AT); and Wellcome Trust grant WT096497 (to DAD).

The funders had no role in study design, data collection and analysis, decision to publish, or preparation of the manuscript.
1. West AP, Shadel GS, Ghosh S: Mitochondria in innate immune responses. Nat Rev Immunol. 2011; 11(6): 389-402.

PubMed Abstract | Publisher Full Text | Free Full Text

2. Nunnari J, Suomalainen A: Mitochondria: in sickness and in health. Cell. 2012; 148(6): 1145-59.

PubMed Abstract | Publisher Full Text

3. Dyall SD, Brown MT, Johnson PJ: Ancient invasions: from endosymbionts to organelles. Science. 2004; 304(5668): 253-7. PubMed Abstract | Publisher Full Text

4. Galluzzi L, Kepp O, Trojel-Hansen C, et al:: Mitochondrial control of cellular life, stress, and death. Circ Res. 2012; 111(9): 1198-207. PubMed Abstract | Publisher Full Text

5. Boyapati RK, Rossi AG, Satsangi J, et al:: Gut mucosal DAMPs in IBD: from mechanisms to therapeutic implications. Mucosal Immunol. 2016; 9(3): 567-82. PubMed Abstract | Publisher Full Text

6. Lee HC, Li SH, Lin JC, et al:: Somatic mutations in the D-loop and decrease in the copy number of mitochondrial DNA in human hepatocellular carcinoma. Mutat Res. 2004; 547(1-2): 71-8. PubMed Abstract | Publisher Full Text
7. Lam NY, Rainer TH, Chiu RW, et al:: Plasma mitochondrial DNA concentrations after trauma. Clin Chem. 2004; 50(1): 213-6. PubMed Abstract | Publisher Full Text

8. $\mathrm{F}$ Zhang $\mathrm{Q}$, Raoof $\mathrm{M}$, Chen $\mathrm{Y}$, et al:: Circulating mitochondrial DAMPs cause inflammatory responses to injury. Nature. 2010; 464(7285): 104-7. PubMed Abstract | Publisher Full Text | Free Full Text | F1000 Recommendation

9. Zhang Q, Itagaki K, Hauser CJ: Mitochondrial DNA is released by shock and activates neutrophils via p38 map kinase. Shock. 2010; 34(1): 55-9. PubMed Abstract | Publisher Full Text

10. Simmons JD, Lee Y, Mulekar S, et al:: Elevated levels of plasma mitochondrial DNA DAMPs are linked to clinical outcome in severely injured human subjects. Ann Surg. 2013; 258(4): 591-6; discussion 596-8. PubMed Abstract | Free Full Text

11. Yamanouchi S, Kudo D, Yamada M, et al:: Plasma mitochondrial DNA levels in patients with trauma and severe sepsis: time course and the association with clinical status. J Crit Care. 2013; 28(6): 1027-31. PubMed Abstract | Publisher Full Text

12. $\mathrm{F}$ Gu X, Yao Y, Wu G, et al.: The plasma mitochondrial DNA is an 
independent predictor for post-traumatic systemic inflammatory response syndrome. PLoS One. 2013; 8(8): e72834.

PubMed Abstract | Publisher Full Text | Free Full Text | F1000 Recommendation

13. Hauser CJ, Sursal T, Rodriguez EK, et al.: Mitochondrial damage associated molecular patterns from femoral reamings activate neutrophils through formy peptide receptors and P44/42 MAP kinase. J Orthop Trauma. 2010; 24(9): 534-8. PubMed Abstract | Publisher Full Text | Free Full Text

14. F Timmermans K, Kox M, Vaneker M, et al:: Plasma levels of dangerassociated molecular patterns are associated with immune suppression in trauma patients. Intensive Care Med. 2016; 42(4): 551-61. PubMed Abstract | Publisher Full Text | F1000 Recommendation

15. F Prikhodko AS, Shabanov AK, Zinovkina LA, et al:: Pure Mitochondrial DNA Does Not Activate Human Neutrophils in vitro. Biochemistry (MoSC). 2015; 80(5): $629-35$

PubMed Abstract | Publisher Full Text | F1000 Recommendation

16. Kung CT, Hsiao SY, Tsai TC, et al.: Plasma nuclear and mitochondrial DNA levels as predictors of outcome in severe sepsis patients in the emergency room. J Transl Med 2012; 10: 130.

PubMed Abstract | Publisher Full Text | Free Full Text

17. F Bhagirath VC, Dwivedi DJ, Liaw PC: Comparison of the Proinflammatory and Procoagulant Properties of Nuclear, Mitochondrial, and Bacterial DNA. Shock. 2015; 44(3): 265-71.

PubMed Abstract | Publisher Full Text | F1000 Recommendation

18. F Timmermans K, Kox M, Scheffer GJ, et al:: Plasma Nuclear and Mitochondrial DNA Levels, and Markers of Inflammation, Shock, and Organ Damage in Patients with Septic Shock. Shock. 2016; 45(6): 607-12. PubMed Abstract | Publisher Full Text | F1000 Recommendation

19. Lu CH, Chang WN, Tsai NW, et al.: The value of serial plasma nuclear and mitochondrial DNA levels in adult community-acquired bacterial meningitis. QJM. 2010; 103(3): 169-75.

PubMed Abstract | Publisher Full Text

20. Garrabou G, Morén C, López S, et al.: The effects of sepsis on mitochondria. J Infect Dis. 2012; 205(3): 392-400. PubMed Abstract | Publisher Full Tex

21. F Di Caro V, Walko TD 3rd, Bola RA, et al.: Plasma Mitochondrial DNA--a Novel DAMP in Pediatric Sepsis. Shock. 2016; 45(5): 506-11. PubMed Abstract | Publisher Full Text | F1000 Recommendation

22. Yu M: Circulating cell-free mitochondrial DNA as a novel cancer biomarker: opportunities and challenges. Mitochondrial DNA. 2012; 23(5): 329-32. PubMed Abstract | Publisher Full Text

23. Nakahira K, Kyung SY, Rogers AJ, et al:: Circulating mitochondrial DNA in patients in the ICU as a marker of mortality: derivation and validation. PLoS Med. 2013; 10(12): e1001577; discussion e1001577. PubMed Abstract | Publisher Full Text | Free Full Text

24. F Krychtiuk KA, Ruhittel S, Hohensinner PJ, et al:: Mitochondrial DNA and TollLike Receptor-9 Are Associated With Mortality in Critically III Patients. Crit Care Med. 2015; 43(12): 2633-41.

PubMed Abstract | Publisher Full Text | F1000 Recommendation

25. F McGill MR, Staggs VS, Sharpe MR, et al:: Serum mitochondrial biomarkers and damage-associated molecular patterns are higher in acetaminophen overdose patients with poor outcome. Hepatology. 2014; 60(4): 1336-45. PubMed Abstract | Publisher Full Text | Free Full Text | F1000 Recommendation

26. Marques PE, Amaral SS, Pires DA, et al:: Chemokines and mitochondrial products activate neutrophils to amplify organ injury during mouse acute liver failure. Hepatology 2012; 56(5): 1971-82.

PubMed Abstract | Publisher Full Text

27. McGill MR, Sharpe MR, Williams CD, et al.: The mechanism underlying acetaminophen-induced hepatotoxicity in humans and mice involves mitochondrial damage and nuclear DNA fragmentation. J Clin Invest. 2012; 122(4): 1574-83. PubMed Abstract | Publisher Full Text | Free Full Text

28. F Bliksoen M, Mariero LH, Ohm IK, et al:: Increased circulating mitochondrial DNA after myocardial infarction. Int J Cardiol. 2012; 158(1): 132-4. PubMed Abstract | Publisher Full Text | F1000 Recommendation

29. Wang $L$, Xie L, Zhang Q, et al:: Plasma nuclear and mitochondrial DNA levels in acute myocardial infarction patients. Coron Artery Dis. 2015; 26(4): 296-300. PubMed Abstract | Publisher Full Text | Free Full Text

30. F Qin C, Gu J, Liu R, et al.: Release of mitochondrial DNA correlates with peak inflammatory cytokines in patients with acute myocardial infarction. Anatol J Cardiol. 2016.

PubMed Abstract | Publisher Full Text | F1000 Recommendation

31. F Liu J, Cai X, Xie L, et al:: Circulating Cell Free Mitochondrial DNA is a Biomarker in the Development of Coronary Heart Disease in the Patients with Type 2 Diabetes. Clin Lab. 2015; 61(7): 661-7.

PubMed Abstract | Publisher Full Text | F1000 Recommendation

32. F Liu J, Zou Y, Tang Y, et al.: Circulating cell-free mitochondrial deoxyribonucleic acid is increased in coronary heart disease patients with diabetes mellitus. J Diabetes Investig. 2016; 7(1): 109-14.

PubMed Abstract | Publisher Full Text | Free Full Text | F1000 Recommendation
33. Tsai NW, Lin TK, Chen SD, et al:: The value of serial plasma nuclear and mitochondrial DNA levels in patients with acute ischemic stroke. Clin Chim Acta. 2011; 412(5-6): 476-9.

PubMed Abstract | Publisher Full Text

34. Wang HC, Yang TM, Lin WC, et al:: The value of serial plasma and cerebrospinal fluid nuclear and mitochondrial deoxyribonucleic acid levels in aneurysmal subarachnoid hemorrhage. J Neurosurg. 2013; 118(1): 13-9.

PubMed Abstract | Publisher Full Text

35. Wang HC, Lin YJ, Lin WC, et al:: The value of serial plasma nuclear and mitochondrial DNA levels in acute spontaneous intra-cerebral haemorrhage. Eur J Neurol. 2012; 19(12): 1532-8.

PubMed Abstract | Publisher Full Text

36. Walko TD 3rd, Bola RA, Hong JD, et al.: Cerebrospinal fluid mitochondrial DNA a novel DAMP in pediatric traumatic brain injury. Shock. 2014; 41(6): 499-503. PubMed Abstract | Publisher Full Text | Free Full Text

37. Hajizadeh S, DeGroot J, TeKoppele JM, et al:: Extracellular mitochondrial DNA and oxidatively damaged DNA in synovial fluid of patients with rheumatoid arthritis. Arthritis Res Ther. 2003; 5(5): R234-40. PubMed Abstract | Publisher Full Text | Free Full Text

38. F Surmiak MP, Hubalewska-Mazgaj M, Wawrzycka-Adamczyk K, et al. Circulating mitochondrial DNA in serum of patients with granulomatosis with polyangiitis. Clin Exp Immunol. 2015; 181(1): 150-5.

PubMed Abstract | Publisher Full Text | Free Full Text | F1000 Recommendation

39. F Caielli S, Athale S, Domic B, et al:: Oxidized mitochondrial nucleoids released by neutrophils drive type I interferon production in human lupus. $J$ Exp Med. 2016; 213(5): 697-713.

PubMed Abstract | Publisher Full Text | Free Full Text | F1000 Recommendation

40. $\mathrm{F}$ Wang $\mathrm{H}, \mathrm{Li} \mathrm{T}$, Chen S, et al.: Neutrophil Extracellular Trap Mitochondrial DNA and Its Autoantibody in Systemic Lupus Erythematosus and a Proof-ofConcept Trial of Metformin. Arthritis Rheumatol. 2015; 67(12): 3190-200. PubMed Abstract | Publisher Full Text | F1000 Recommendation

41. F Lood C, Blanco LP, Purmalek MM, et al:: Neutrophil extracellular traps enriched in oxidized mitochondrial DNA are interferogenic and contribute to lupus-like disease. Nat Med. 2016; 22(2): 146-53.

PubMed Abstract | Publisher Full Text | Free Full Text | F1000 Recommendation

42. F Garcia-Martinez I, Santoro N, Chen Y, et al:: Hepatocyte mitochondrial DNA drives nonalcoholic steatohepatitis by activation of TLR9. J Clin Invest. 2016; 126(3): 859-64.

PubMed Abstract | Publisher Full Text | Free Full Text | F1000 Recommendation

43. Collins LV, Hajizadeh S, Holme E, et al.: Endogenously oxidized mitochondrial DNA induces in vivo and in vitro inflammatory responses. J Leukoc Biol. 2004; 75(6): 995-1000.

PubMed Abstract | Publisher Full Text

44. F Hu Q, Wood CR, Cimen S, et al:: Mitochondrial Damage-Associated Molecular Patterns (MTDs) Are Released during Hepatic Ischemia Reperfusion and Induce Inflammatory Responses. PLoS One. 2015; 10(10): e0140105. PubMed Abstract | Publisher Full Text | Free Full Text | F1000 Recommendation

45. F Tsuji N, Tsuji T, Ohashi N, et al.: Role of Mitochondrial DNA in Septic AKI via Toll-Like Receptor 9. J Am Soc Nephrol. 2016; 27(7): 2009-20.

PubMed Abstract | Publisher Full Text | Free Full Text | F1000 Recommendation

46. F Gan L, Chen X, Sun T, et al:: Significance of Serum mtDNA Concentration in Lung Injury Induced by Hip Fracture. Shock. 2015; 44(1): 52-7. PubMed Abstract | Publisher Full Text | F1000 Recommendation

47. F Latz E, Schoenemeyer A, Visintin A, et al:: TLR9 signals after translocating from the ER to CpG DNA in the lysosome. Nat Immunol. 2004; 5(2): 190-8. PubMed Abstract | Publisher Full Text | F1000 Recommendation

48. Leifer CA, Kennedy MN, Mazzoni A, et al.: TLR9 is localized in the endoplasmic reticulum prior to stimulation. $J$ Immunol. 2004; 173(2): 1179-83. PubMed Abstract | Publisher Full Text | Free Full Text

49. Moseman EA, Liang X, Dawson AJ, et al:: Human plasmacytoid dendritic cells activated by $\mathrm{CpG}$ oligodeoxynucleotides induce the generation of $\mathrm{CD} 4{ }^{+} \mathrm{CD} 25$ regulatory T cells. J Immunol. 2004; 173(7): 4433-42.

PubMed Abstract | Publisher Full Text

50. Hemmi H, Takeuchi O, Kawai T, et al:: A Toll-like receptor recognizes bacterial DNA. Nature. 2000; 408(6813): 740-5. PubMed Abstract | Publisher Full Text

51. Bauer S, Kirschning CJ, Häcker $\mathrm{H}$, et al:: Human TLR9 confers responsiveness to bacterial DNA via species-specific CpG motif recognition. Proc Natl Acad Sci U S A. 2001; 98(16): 9237-42. PubMed Abstract | Publisher Full Text | Free Full Text

52. F Sasai M, Linehan MM, Iwasaki A: Bifurcation of Toll-like receptor 9 signaling by adaptor protein 3 . Science. 2010; 329(5998): 1530-4. PubMed Abstract | Publisher Full Text | Free Full Text | F1000 Recommendation

53. Petrasek J, Dolganiuc A, Csak T, et al:: Type I interferons protect from Toll-like receptor 9-associated liver injury and regulate IL-1 receptor antagonist in mice. Gastroenterology. 2011; 140(2): 697-708.e4. PubMed Abstract | Publisher Full Text | Free Full Text

54. F Wei X, Shao B, He Z, et al:: Cationic nanocarriers induce cell necrosis through impairment of $\mathrm{Na}^{+} / \mathrm{K}^{+}-\mathrm{ATPase}$ and cause subsequent inflammatory 
response. Cell Res. 2015; 25(2): 237-53.

PubMed Abstract | Publisher Full Text | Free Full Text | F1000 Recommendation

55. F Bakker PJ, Scantlebery AM, Butter LM, et al.: TLR9 Mediates Remote Live Injury following Severe Renal Ischemia Reperfusion. PLoS One. 2015; 10(9): e0137511.

PubMed Abstract | Publisher Full Text | Free Full Text | F1000 Recommendation

56. Arnalich F, Codoceo R, López-Collazo E, et al.: Circulating cell-free mitochondrial DNA: a better early prognostic marker in patients with out-ofhospital cardiac arrest. Resuscitation. 2012; 83(7): e162-3. PubMed Abstract | Publisher Full Text

57. F Sudakov NP, Popkova TP, Katyshev Al, et al.: Level of Blood Cell-Free Circulating Mitochondrial DNA as a Novel Biomarker of Acute Myocardial Ischemia. Biochemistry (Mosc). 2015; 80(10): 1387-92. PubMed Abstract | Publisher Full Text | F1000 Recommendation

58. F Gu X, Wu G, Yao Y, et al.: Intratracheal administration of mitochondrial DNA directly provokes lung inflammation through the TLR9-p38 MAPK pathway. Free Radic Biol Med. 2015; 83: 149-58. PubMed Abstract | Publisher Full Text | F1000 Recommendation

59. Barton GM, Kagan JC: A cell biological view of Toll-like receptor function: regulation through compartmentalization. Nat Rev Immunol. 2009; 9(8): 535-42. PubMed Abstract | Publisher Full Text | Free Full Text

60. Ziello JE, Huang Y, Jovin IS: Cellular endocytosis and gene delivery. Mol Med. 2010; 16(5-6): 222-9.

PubMed Abstract | Publisher Full Text | Free Full Text

61. Maeda A, Fadeel B: Mitochondria released by cells undergoing TNF- $\alpha$-induced necroptosis act as danger signals. Cell Death Dis. 2014; 5: e1312. PubMed Abstract | Publisher Full Text | Free Full Text

62. Zitvogel L, Kepp O, Kroemer G: Decoding cell death signals in inflammation and immunity. Cell. 2010; 140(6): 798-804. PubMed Abstract | Publisher Full Text

63. Tian J, Avalos AM, Mao SY, et al:: Toll-like receptor 9-dependent activation by DNA-containing immune complexes is mediated by HMGB1 and RAGE. Nat Immunol. 2007; 8(5): 487-96.

PubMed Abstract | Publisher Full Text

64. Viglianti GA, Lau CM, Hanley TM, et al: Activation of autoreactive $\mathbf{B}$ cells by CpG dsDNA. Immunity. 2003; 19(6): 837-47. PubMed Abstract | Publisher Full Text

65. Dasari P, Nicholson IC, Hodge G, et al:: Expression of toll-like receptors on $B$ lymphocytes. Cell Immunol. 2005; 236(1-2): 140-5. PubMed Abstract | Publisher Full Text

66. Baiyee EE, Flohe S, Lendemans S, et al.: Expression and function of Toll-like receptor 9 in severely injured patients prone to sepsis. Clin Exp Immunol. 2006; 145(3): 456-62.

PubMed Abstract | Publisher Full Text | Free Full Text

67. Eaton-Bassiri A, Dillon SB, Cunningham M, et al.: Toll-like receptor 9 can be expressed at the cell surface of distinct populations of tonsils and human peripheral blood mononuclear cells. Infect Immun. 2004; 72(12): 7202-11. PubMed Abstract | Publisher Full Text | Free Full Text

68. Saikh KU, Kissner TL, Sultana A, et al.: Human monocytes infected with Yersinia pestis express cell surface TLR9 and differentiate into dendritic cells. J Immunol. 2004; 173(12): 7426-34.

PubMed Abstract | Publisher Full Text

69. Lindau D, Mussard J, Wagner BJ, et al:: Primary blood neutrophils express a functional cell surface Toll-like receptor 9. Eur J Immunol. 2013; 43(8): 2101-13. PubMed Abstract | Publisher Full Text

70. Lee J, Mo JH, Shen C, et al.: Toll-like receptor signaling in intestinal epithelial cells contributes to colonic homoeostasis. Curr Opin Gastroenterol. 2007; 23(1): 27-31.

PubMed Abstract | Publisher Full Text

71. Ewaschuk JB, Backer JL, Churchill TA, et al: Surface expression of Toll-like receptor 9 is upregulated on intestinal epithelial cells in response to pathogenic bacterial DNA. Infect Immun. 2007; 75(5): 2572-9. PubMed Abstract | Publisher Full Text | Free Full Text

72. Gurung P, Lukens JR, Kanneganti TD: Mitochondria: diversity in the regulation of the NLRP3 inflammasome. Trends Mol Med. 2015; 21(3): 193-201. PubMed Abstract | Publisher Full Text | Free Full Text

73. F Nakahira K, Haspel JA, Rathinam VA, et al:: Autophagy proteins regulate innate immune responses by inhibiting the release of mitochondrial DNA mediated by the NALP3 inflammasome. Nat Immunol. 2011; 12(3): 222-30. PubMed Abstract | Publisher Full Text | Free Full Text | F1000 Recommendation

74. F Zhou R, Yazdi AS, Menu P, et al:: A role for mitochondria in NLRP3 inflammasome activation. Nature. 2011; 469(7329): 221-5. PubMed Abstract | Publisher Full Text | F1000 Recommendation

75. F Shimada K, Crother TR, Karlin J, et al:: Oxidized mitochondrial DNA activates the NLRP3 inflammasome during apoptosis. Immunity. 2012; 36(3): 401-14. PubMed Abstract | Publisher Full Text | Free Full Text | F1000 Recommendation

76. Zhang Z, Xu X, Ma J, et al.: Gene deletion of Gabarap enhances Nirp3 inflammasome-dependent inflammatory responses. J Immunol. 2013; 190(7): 3517-24.

PubMed Abstract | Publisher Full Text

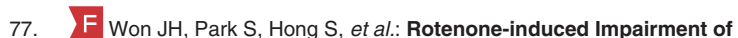
Mitochondrial Electron Transport Chain Confers a Selective Priming Signal for NLRP3 Inflammasome Activation. J Biol Chem. 2015; 290(45): 27425-37. PubMed Abstract | Publisher Full Text | Free Full Text | F1000 Recommendation

78. Dombrowski Y, Peric M, Koglin S, et al:: Honey bee (Apis mellifera) venom induces AIM2 inflammasome activation in human keratinocytes. Allergy. 2012; 67(11): $1400-7$.

PubMed Abstract | Publisher Full Text

79. Holmström KM, Finkel T: Cellular mechanisms and physiological consequences of redox-dependent signalling. Nat Rev Mol Cell Biol. 2014; 15(6): 411-21. PubMed Abstract | Publisher Full Text

80. Ding Z, Liu S, Wang X, et al.: LOX-1, mtDNA damage, and NLRP3 inflammasome activation in macrophages: implications in atherogenesis. Cardiovasc Res. 2014; 103(4): 619-28. PubMed Abstract | Publisher Full Text | Free Full Text

81. Nakahira K, Hisata S, Choi AM: The Roles of Mitochondrial Damage-Associated Molecular Patterns in Diseases. Antioxid Redox Signal. 2015; 23(17): 1329-50. PubMed Abstract | Publisher Full Text | Free Full Text

82. Bauernfeind FG, Horvath G, Stutz A, et al:: Cutting edge: NF-kappaB activating pattern recognition and cytokine receptors license NLRP3 inflammasome activation by regulating NLRP3 expression. J Immunol. 2009; 183(2): 787-91. PubMed Abstract | Publisher Full Text | Free Full Text

83. Imaeda AB, Watanabe A, Sohail MA, et al:: Acetaminophen-induced hepatotoxicity in mice is dependent on TIr9 and the Nalp3 inflammasome. $J$ Clin Invest. 2009; 119(2): 305-14.

PubMed Abstract | Publisher Full Text | Free Full Text

84. Williams CD, Antoine DJ, Shaw PJ, et al:: Role of the Nalp3 inflammasome in acetaminophen-induced sterile inflammation and liver injury. Toxicol Appl Pharmacol. 2011; 252(3): 289-97. PubMed Abstract | Publisher Full Text | Free Full Tex

85. F Ishikawa $\mathrm{H}$, Barber GN: STING is an endoplasmic reticulum adaptor that facilitates innate immune signalling. Nature. 2008; 455(7213): 674-8. PubMed Abstract | Publisher Full Text | Free Full Text | F1000 Recommendation

86. Barber GN: STING-dependent cytosolic DNA sensing pathways. Trends Immunol. 2014; 35(2): 88-93. PubMed Abstract | Publisher Full Text

87. F Rongvaux A, Jackson R, Harman CC, et al:: Apoptotic caspases prevent the induction of type I interferons by mitochondrial DNA. Cell. 2014; 159(7): 1563-77.

PubMed Abstract | Publisher Full Text | Free Full Text | F1000 Recommendation

88. F White MJ, McArthur K, Metcalf D, et al.: Apoptotic caspases suppress mtDNA-induced STING-mediated type I IFN production. Cell. 2014; 159(7): 1549-62.

PubMed Abstract | Publisher Full Text | Free Full Text | F1000 Recommendation

89. F West AP, Khoury-Hanold W, Staron M, et al:: Mitochondrial DNA stress primes the antiviral innate immune response. Nature. 2015; 520(7548): 553-7. PubMed Abstract | Publisher Full Text | Free Full Text | F1000 Recommendation

90. Patrushev M, Kasymov V, Patrusheva V, et al:: Mitochondrial permeability transition triggers the release of mtDNA fragments. Cell Mol Life Sci. 2004; 61(24): 3100-3

PubMed Abstract | Publisher Full Text

91. Ding $Z$, Liu S, Wang $X$, et al:: Oxidant stress in mitochondrial DNA damage, autophagy and inflammation in atherosclerosis. Sci Rep. 2013; 3: 1077. PubMed Abstract | Publisher Full Text | Free Full Text

92. Kaczmarek A, Vandenabeele P, Krysko DV: Necroptosis: the release of damageassociated molecular patterns and its physiological relevance. Immunity. 2013; 38(2): 209-23.

PubMed Abstract | Publisher Full Text

93. Mangalmurti N, Qing D, Hotz M, et al.: Mitochondrial DNA Released Following Necroptosis Accumulates on RBCs. Am J Respir Crit Care Med. 2016; 193: A4309. Reference Source

94. Boudreau LH, Duchez AC, Cloutier N, et al:: Platelets release mitochondria serving as substrate for bactericidal group IIA-secreted phospholipase $A_{2}$ to promote inflammation. Blood. 2014; 124(14): 2173-83. PubMed Abstract | Publisher Full Text | Free Full Text

95. F Xin G, Wei Z, Ji C, et al:: Metformin Uniquely Prevents Thrombosis by Inhibiting Platelet Activation and mtDNA Release. Sci Rep. 2016; 6: 36222. PubMed Abstract | Publisher Full Text | Free Full Text | F1000 Recommendation

96. F Islam MN, Das SR, Emin MT, et al.: Mitochondrial transfer from bonemarrow-derived stromal cells to pulmonary alveoli protects against acute lung injury. Nat Med. 2012; 18(5): 759-65.

PubMed Abstract | Publisher Full Text | Free Full Text | F1000 Recommendation

97. Waldenström A, Gennebäck N, Hellman U, et al:: Cardiomyocyte microvesicles contain DNA/RNA and convey biological messages to target cells. PLOS One. 2012; 7(4): e34653.

PubMed Abstract | Publisher Full Text | Free Full Text

98. Balaj L, Lessard R, Dai L, et al:: Tumour microvesicles contain retrotransposon elements and amplified oncogene sequences. Nat Commun. 2011; 2: 180. PubMed Abstract | Publisher Full Text | Free Full Text

99. Guescini M, Guidolin D, Vallorani L, et al:: C2C12 myoblasts release micro- 
vesicles containing mtDNA and proteins involved in signal transduction. Exp Cell Res. 2010; 316(12): 1977-84.

PubMed Abstract | Publisher Full Text

100. Guescini M, Genedani S, Stocchi V, et al:: Astrocytes and Glioblastoma cells release exosomes carrying mtDNA. J Neural Transm (Vienna). 2010; 117(1): 1-4 PubMed Abstract | Publisher Full Text

101. Pazmandi K, Agod Z, Kumar BV, et al.: Oxidative modification enhances the immunostimulatory effects of extracellular mitochondrial DNA on plasmacytoid dendritic cells. Free Radic Biol Med. 2014; 77: 281-90. PubMed Abstract | Publisher Full Text

102. Oka T, Hikoso S, Yamaguchi $\mathrm{O}$, et al.: Mitochondrial DNA that escapes from autophagy causes inflammation and heart failure. Nature. 2012; 485(7397): 251-5.

PubMed Abstract | Publisher Full Text | Free Full Text

103. Boyapati R, Satsangi J, Ho G: Pathogenesis of Crohn's disease. F1000Prime Rep. 2015; 7: 44.

PubMed Abstract | Publisher Full Text | Free Full Text

104. Botezatu I, Serdyuk O, Potapova G, et al:: Genetic analysis of DNA excreted in urine: a new approach for detecting specific genomic DNA sequences from cells dying in an organism. Clin Chem. 2000; 46(8 Pt): 1078-84. PubMed Abstract

105. F Whitaker RM, Stallons $L J$, Kneff JE, et al:: Urinary mitochondrial DNA is a biomarker of mitochondrial disruption and renal dysfunction in acute kidney injury. Kidney Int. 2015; 88(6): 1336-44.

PubMed Abstract | Publisher Full Text | Free Full Text | F1000 Recommendation

106. Stacey KJ, Sweet MJ, Hume DA: Macrophages ingest and are activated by bacterial DNA. J Immunol. 1996; 157(5): 2116-22. PubMed Abstract

107. Lo YM, Zhang J, Leung TN, et al:: Rapid clearance of fetal DNA from maternal plasma. Am J Hum Genet. 1999; 64(1): 218-24. PubMed Abstract | Publisher Full Text | Free Full Text

108. Okabe $\mathrm{Y}$, Kawane $\mathrm{K}$, Akira S, et al.: Toll-like receptor-independent gen induction program activated by mammalian DNA escaped from apoptotic DNA degradation. J Exp Med. 2005; 202(10): 1333-9. PubMed Abstract | Publisher Full Text | Free Full Text

109. F Chan MP, Onji M, Fukui R, et al.: DNase II-dependent DNA digestion is required for DNA sensing by TLR9. Nat Commun. 2015; 6 : 5853. PubMed Abstract | Publisher Full Text | F1000 Recommendation

110. F Dhondup Y, Ueland T, Dahl CP, et al.: Low Circulating Levels of Mitochondrial and High Levels of Nuclear DNA Predict Mortality in Chronic Heart Failure. J Card Fail. 2016; 22(10): 823-8. PubMed Abstract | Publisher Full Text | F1000 Recommendation

111. Kohler C, Radpour R, Barekati Z, et al.: Levels of plasma circulating cell free nuclear and mitochondrial DNA as potential biomarkers for breast tumors. Mol Cancer. 2009; 8: 105 PubMed Abstract | Publisher Full Text | Free Full Text

112. Zachariah RR, Schmid S, Buerki N, et al:: Levels of circulating cell-free nuclear and mitochondrial DNA in benign and malignant ovarian tumors. Obstet Gynecol. 2008; 112(4): 843-50. PubMed Abstract | Publisher Full Text

113. Ellinger J, Albers $P$, Müller SC, et al.: Circulating mitochondrial DNA in the serum of patients with testicular germ cell cancer as a novel noninvasive diagnostic biomarker. BJU Int. 2009; 104(1): 48-52. PubMed Abstract | Publisher Full Text

114. Ellinger J, Müller DC, Müller SC, et al.: Circulating mitochondrial DNA in serum: a universal diagnostic biomarker for patients with urological malignancies. Urol Oncol. 2012; 30(4): 509-15. PubMed Abstract | Publisher Full Tex

115. Ellinger J, Müller SC, Wernert N, et al.: Mitochondrial DNA in serum of patients with prostate cancer: a predictor of biochemical recurrence after prostatectomy. BJU Int. 2008; 102(5): 628-32. PubMed Abstract | Publisher Full Text

116. Yu M, Wan YF, Zou QH: Cell-free circulating mitochondrial DNA in the serum: a potential non-invasive biomarker for Ewing's sarcoma. Arch Med Res. 2012; 43(5): 389-94.

PubMed Abstract | Publisher Full Text

117. Hou YL, Chen JJ, Wu YF, et al:: Clinical significance of serum mitochondrial DNA in lung cancer. Clin Biochem. 2013; 46(15): 1474-7. PubMed Abstract | Publisher Full Text

118. Mehra N, Penning M, Maas J, et al:: Circulating mitochondrial nucleic acids have prognostic value for survival in patients with advanced prostate cancer. Clin Cancer Res. 2007; 13(2 Pt 1): 421-6. PubMed Abstract | Publisher Full Text

119. Huang $\mathrm{CY}$, Chen $\mathrm{YM}, \mathrm{Wu} \mathrm{CH}$, et al.: Circulating free mitochondrial DNA concentration and its association with erlotinib treatment in patients with adenocarcinoma of the lung. Oncol Lett. 2014; 7(6): 2180-4.

PubMed Abstract | Publisher Full Text | Free Full Text

120. Budnik LT, Kloth S, Baur X, et al: Circulating mitochondrial DNA as biomarker linking environmental chemical exposure to early preclinical lesions elevation of mtDNA in human serum after exposure to carcinogenic halo-alkane-based pesticides. PLoS One. 2013; 8(5): e64413.

PubMed Abstract | Publisher Full Text | Free Full Text

121. Lu H, Busch J, Jung M, et al:: Diagnostic and prognostic potential of circulating cell-free genomic and mitochondrial DNA fragments in clear cell renal cell carcinoma patients. Clin Chim Acta. 2016; 452: 109-19. PubMed Abstract | Publisher Full Text

122. Cossarizza A, Pinti M, Nasi M, et al: Increased plasma levels of extracellular mitochondrial DNA during HIV infection: a new role for mitochondrial damageassociated molecular patterns during inflammation. Mitochondrion. 2011; 11(5): $750-5$.

PubMed Abstract | Publisher Full Text

123. Dai Z, Cai W, Hu F, et al.: Plasma Mitochondrial DNA Levels as a Biomarker of Lipodystrophy Among HIV-infected Patients Treated with Highly Active Antiretroviral Therapy (HAART). Curr Mol Med. 2015; 15(10): 975-9. PubMed Abstract | Publisher Full Text

124. Lauring AS, Lee TH, Martin JN, et al:: Lack of evidence for mtDNA as a biomarke of innate immune activation in HIV infection. PLOS One. 2012; 7(11): e50486. PubMed Abstract | Publisher Full Text | Free Full Text

125. Pinti M, Cevenini $\mathrm{E}$, Nasi $\mathrm{M}$, et al:: Circulating mitochondrial DNA increases with age and is a familiar trait: Implications for "inflamm-aging". Eur J Immunol. 2014; 44(5): 1552-62. PubMed Abstract | Publisher Full Text

126. Verschoor CP, Loukov D, Naidoo A, et al:: Circulating TNF and mitochondrial DNA are major determinants of neutrophil phenotype in the advanced-age, frail elderly. Mol Immunol. 2015; 65(1): 148-56. PubMed Abstract | Publisher Full Text

127. Jylhävä J, Nevalainen T, Marttila S, et al:: Characterization of the role of distinct plasma cell-free DNA species in age-associated inflammation and frailty. Aging Cell. 2013; 12(3): 388-97.

PubMed Abstract | Publisher Full Text

128. Shockett PE, Khanal J, Sitaula A, et al.: Plasma cell-free mitochondrial DNA declines in response to prolonged moderate aerobic exercise. Physiol Rep. 2016; 4(1): pii: e12672.

PubMed Abstract | Publisher Full Text | Free Full Text

129. Nasi M, Cristani A, Pinti M, et al:: Decreased Circulating mtDNA Levels in Professional Male Volleyball Players. Int J Sports Physiol Perform. 2016; 11(1): 116-21.

PubMed Abstract | Publisher Full Text

130. Chou CC, Fang HY, Chen YL, et al.: Plasma nuclear DNA and mitochondrial DNA as prognostic markers in corrosive injury patients. Dig Surg. 2008; 25(4): 300-4. PubMed Abstract | Publisher Full Text

131. Sabatino L, Botto N, Borghini A, et al.: Development of a new multiplex quantitative real-time PCR assay for the detection of the mtDNA $\mathrm{A}^{4977}$ deletion in coronary artery disease patients: a link with telomere shortening. Environ Mol Mutagen. 2013; 54(5): 299-307.

PubMed Abstract | Publisher Full Text

132. Zhang B, Angelidou A, Alysandratos KD, et al:: Mitochondrial DNA and antimitochondrial antibodies in serum of autistic children. $J$ Neuroinflammation. 2010; 7: 80 .

PubMed Abstract | Publisher Full Text | Free Full Text

133. Cao $\mathrm{H}, \mathrm{Ye} \mathrm{H}$, Sun $\mathrm{Z}$, et al.: Circulatory mitochondrial DNA is a pro-inflammatory agent in maintenance hemodialysis patients. PLOS One. 2014; 9(12): e113179. PubMed Abstract | Publisher Full Text | Free Full Text

134. Zhang $\mathrm{Y}, \mathrm{Zhao} \mathrm{Y}$, Wen $\mathrm{S}$, et al.: Associations of mitochondrial haplogroups and mitochondrial DNA copy numbers with end-stage renal disease in a Han population. Mitochondrial DNA A DNA Mapp Seq Anal. 2016: 1-7. PubMed Abstract | Publisher Full Text

135. Stertz L, Fries GR, Rosa AR, et al:: Damage-associated molecular patterns and immune activation in bipolar disorder. Acta Psychiatr Scand. 2015; 132(3): 211-7. PubMed Abstract | Publisher Full Text

136. Borghini A, Mercuri A, Turchi S, et al.: Increased circulating cell-free DNA levels and mtDNA fragments in interventional cardiologists occupationally exposed to low levels of ionizing radiation. Environ Mol Mutagen. 2015; 56(3): 293-300. PubMed Abstract | Publisher Full Text

137. F Dantham S, Srivastava AK, Gulati S, et al.: Plasma circulating cell-free mitochondrial DNA in the assessment of Friedreich's ataxia. J Neurol Sci. 2016; 365: 82-8.

PubMed Abstract | Publisher Full Text | F1000 Recommendation

138. F Yasui K, Matsuyama N, Kuroishi A, et al:: Mitochondrial damage-associated molecular patterns as potential proinflammatory mediators in post-platelet transfusion adverse effects. Transfusion. 2016; 56(5): 1201-12. PubMed Abstract | Publisher Full Text | F1000 Recommendation 


\section{Open Peer Review}

\section{Current Peer Review Status:}

\section{Editorial Note on the Review Process}

Faculty Reviews are review articles written by the prestigious Members of Faculty Opinions. The articles are commissioned and peer reviewed before publication to ensure that the final, published version is comprehensive and accessible. The reviewers who approved the final version are listed with their names and affiliations.

\section{The reviewers who approved this article are:}

\section{Version 1}

\section{Augustine M.K. Choi}

Division of Pulmonary and Critical Care Medicine, Joan and Sanford I. Weill Department of Medicine, Weill Cornell Medicine, New York, NY, USA

\section{Kiichi Nakahira}

Department of Medicine, Weill Cornell Medicine, New York, NY, USA

Competing Interests: No competing interests were disclosed.

\section{Mitchell R. McGill}

Department of Pathology and Immunology, Washington University School of Medicine, St Louis, MO, 63110, USA

Competing Interests: No competing interests were disclosed.

\section{Antonio Ferrante}

Women and Children's Hospital Campus, University of Adelaide, Adelaide, Australia

Competing Interests: No competing interests were disclosed. 
The benefits of publishing with F1000Research:

- Your article is published within days, with no editorial bias

- You can publish traditional articles, null/negative results, case reports, data notes and more

- The peer review process is transparent and collaborative

- Your article is indexed in PubMed after passing peer review

- Dedicated customer support at every stage

For pre-submission enquiries, contact research@f1000.com 